\title{
Perbedaan Kontribusi Permainan Benteng, Menaruh Bola Terhadap Keterampilan Gerak Dasar Lari Pada Siswa Taman Kanak-Kanak Kelurahan Payo Selincah Kota Jambi
}

\author{
Ilham, Hendri Munar, Alek Oktadinata
}

Correspondence: Fakultas Ilmu Keolahragaan, Universitas Jambi, Jambi, Indonesia. E-mail: $\underline{\text { llhambugis@unja.ac.id, (hendrimunar@unja.ac.id, alekoktadinata@unja.ac.id }}$

\begin{abstract}
Abstrak
Penelitian ini untuk mengetahui kontribusi permainan perbedaan kontribusi memalui permainan lari dengan permainan benteng dan permainan menaruh bola terhadap kemampuan gerak dasar lari siswa Taman Kanak-Kanak Kelurahan Payo Selincah Kota Jambi, secara khusus penelitian bertujuan untuk mengetahui: (1) Kontribusi permainan benteng terhadap keteampilan gerak dasar lari (2) Kontribusi permainan memindahkan bola terhadap keterampilan gerak dasar lari (3) Perbedaan kontribusi permainan benteng dan memindahkan bola terhadap keterampilan gerak dasar lari. Metode yang digunakan eksperimen, penelitian ini terdapat perlakuan yaitu permainan benteng dan menaruh bola, untuk mengetahui kontribusi terhadap kemampuan gerak dasar lari. Sampel dalam penelitian ini adalah siswa TK Bintang Kelurahan Payo selincah sebanyak 46 orang siswa. Data yang terkumpul dianalisis dengan menggunakan uji $t$ namun sebelumnya dilakukan uji normalitas dan homogenitas. Kesimpulan dari penelitian ini (1) Permainan benteng memberikan kontribusi terhadap peningkatan keterampilan gerak dasar lari pada siswa TK Bintang kelurahan payo selincah (2) Permainan memindahkan bola memberikan kontribusi terhadap peningkatan keterampilan gerak dasar lari pada siswa TK Bintang kelurahan payo selincah (3) Permainan memindahkan bola memiliki kontribusi yang lebih baik dari pada permainan benteng terhadap peningkatan keterampilan gerak dasar lari pada siswa TK Bintang kelurahan payo selincah.
\end{abstract}

\section{Kata Kunci: Keterampilan Gerak Dasar Lari}

\section{Pendahuluan}

Perkembangan ekonomi saat ini semakin pesat. Hal ini dibuktikan dengan adanya Masyarakat Ekonmi Asean. Untuk menanggapi hal tersebut pemerintah harus mempersiapkan sumber daya manusia yang berkualitas. Salah satu uapaya yang perlu dipersiapkan melalui pendidikan. Pendidikan salah satu cara untuk menciptakan sumber daya manusia mampu bersaing dengan sumber daya manusia dari negara lain. Pendidikan hendaknya dimulai sejak dini karena pendidikan usia dini dapat membentuk generasi muda yang handal. Pendidikan usia dini yang formal dimulai dari Pendidikan Taman Kanak-Kanak. Taman Kanak-Kanak pada umumnya 
merupakan bentuk pendidikan prasekolah yang menyediakan program pendidikan dini yang diperlukan oleh siswa dalam menyesuaikan diri dengan lingkungannya dan untuk kehidupan selanjutnya.

Pelaksanaan pendidikan di TK menganut prinsip: "Bermain sambil Belajar dan Belajar seraya Bermain". Pada usia sekolah taman kanak-kanak siswa diberi materi belajar gerakan multilateral yang bertujuan agar siswa mampu mengembangkan semua unsur psikis dan fisik yang ada pada dirinya. The years from 2 to 6 are considered the "golden years" of motor development. (Hayes, 1994; Williams, 1983 dalam Williams and Monsma; 2006). Ini membuktikan bahwa masa pada usia 2 samapai 6 tahun merupakan "tahun emas" masa perkembangan motorik. Pada masa tersebut pembelajaran akan memberi bekas yang kuat dan tahan lama. Kesalahan dalam belajar memberikan efek negatif pada siswa dalam jangka panjang dan sulit untuk diperbaiki. Oleh karena itu, pada masa usia dini merupakan waktu yang paling baik bagi seorang anak untuk memperoleh pendidikan.

Pada kurikulum taman kanak-kanak pedoman pengembangan program pembelajaran di Taman Kanak-Kanak yang diterbitkan oleh kementrian pendidikan nasional tahun 2013 terdapat pencapaian lingkup perkembangan siswa pada aspek fisik yaitu melakukan garakan melompat, meloncat dan berlari secara terkoordinasi.

Selama ini proses pembelajaran pendidikan jasmani yang diterapkan di sekolah masih jauh dari yang kita harapkan. Proses pendidikan jasmani disekolah khususnya di taman kanak-kanak belum sepenuhnya mengarah ke peningkatkan perkembangan gerak dasar. Apabila ini tidak ditanggapi dengan serius maka murid pada taman kakak-kanak akan salah melakukan gerak dasar dan itu akan terekam di dalam memori otaknya seumur hidup. Hal ini akan berdampak buruk pada pertumbuhan anak tersebut khususnya dalam melakukan aktivitas sehari-hari.

Kenyataan menunjukkan bahwa proses pendidikan dan pengajaran yang dikembangkan oleh berbagai tenaga pengajar belum menunjukkan pola pengajaran yang sesuai dengan apa yang diharapkan. Bila melihat model pembelajaran yang dikembangkan oleh guru masih belum mampu memenuhi dalam perkembangan gerak dasar.

Permainan pembelajaran gerak dasar dibuat lebih menarik dan penuh tantangan sehingga murid-murid dapat termotivasi, dan mereka lebih senang mengikuti pelajaran, maka perlu dilakukan penelitian terhadap murid di taman kanakkanak tentang penerapan modifikasi permainan terhadap kemampuan gerak dasar.

Keberhasilan siswa tidak hanya ditentukan oleh hasil pembelajaranya, akan tetapi dipengaruhi oleh proses belajar mengajar yang dilakukan oleh guru. Apabila suatu kegiatan pembelajaran dilakukan dengan proses pembelajaran yang baik, maka pencapaian hasil belajar yang diharapkan akan tercapai dengan baik. Karena guru merupakan unsur penangung jawab dalam pelaksanaan proses belajar mengajar maka, guru harus benar-benar merancang model pembelajaran untuk mencapai hasil belajar yang diharapkan

Melihat proses belajar-mengajar di Taman Kanak-kanak yang dilakukan selama ini guru masih belum memanfaatkan permainan sebagai media pembelajaran. 
Dalam menerapkan permainan dalam pembelajaran siswa akan merasa senang dan termotivasi dalam mengikuti pelajaran. Barkaitan dengan hal di atas maka sangat tepat bila guru pada taman kanak-kanak menggunakan pendekatan bermain, dalam proses belajar mengajar penjas di taman kanak-kanak untuk pencapaian indicator pembelajaran.

Dengan adanya permasalahan pada analisis situasi di atas diperlukan penerapan model latihan gerak dasar memalui permainan dalam pencapaian indicator pembelajaran, karena dengan metode tersebut dapat memberikan motivasi belajar.

Pelaksanaan permainan lari dengan menggunakan permainan tradisional dan menggunakan alat bantu dalam permainan memindahkan bola membutuhkan kecepatan berlari, kelincahan, kekuatan, kelentukan, kecepatan reaksi, karena itu peneliti berasumsih bahwa permainan tersebut dapat digunakan sebagai media pembelajaran untuk membentukan kemampuan gerak dasar lari. Berdasarkan asumsi tersebut maka peneliti ingin mengetahui apakah permainan lari dengan menggunakan permainan benteng dan memindahkan bola dapat membentuk kemampuan gerak dasar lari pada siswa Taman Kanak-Kanak Kelurahan Payo Selincah Kota Jambi.

Adapun tujuan penelitian ini adalah: (1) Kontribusi melalui penerapan permainan benteng terhadap kemampuan gerak dasar lari, (2) Kontribusi melalui penerapan permainan memindahkan bola terhadap kemampuan gerak dasar lari, (3) Perbedaan kontribusi melalui penerapan permainan benteng dan memindahkan bola terhadap kemampuan gerak dasar lari.

Manfaat penelitian ini adalah: (1) Bagi guru penjas yaitu sebagai informasi bentuk permainan yang dapat digunakan sebagai media pembelajaran untuk pencapaian indikator kemampuan gerak dasar lari, (2) Bagi pelatih pemula bahwa untuk membentuk keterampilan dasar pada atlet dapat dilakukan dengan modifikasi permain tradisional dengan penerapan modifikasi permainan, (3) Bagi akdemisi bahwa penelitian ini sebagai bahan referensi dan wawasan khasana keilmuan khususnya dalam penerapan pembelajaran olahraga dapat mengunakan permainan untuk mencapai indicator pembelajaran gerak dasar lari, (4) Bagi mahasiswa atau atlet bahwa permainan modifikasi permainan trdisional tanpa alat dengan penerapan modifikasi permainan dapat digunakan sebagai media pembelajaran dan latihan untuk pencapaian keterampilan gerak dasar lari.

\section{Pustaka}

"Running is an exaggerated form walking. It differs principally from the walk in that there is a brief flight phase during each step, in which body is out contact with the supporting surface" (Gallahue and Ozmun, 2006; 204) maksudnya "lari merupakan tingkatan dari berjalan. Lari berbeda prinsip dari berjalan. Lari ada fase melayang yang singkat dalam setiap langkahnya, dimana tubuh tidak berhubungan dengan permukaan tumpuan". Gerakan lari yang baik dimana kaki di anggkat kedepan kemudian ditolakkan dengan kuat kemudan angkat paha, ayunkan lengan untuk keseimbangan dan dorongan kedepan. Berlari merupakan suatu kegiatan yang dapat dilakukan oleh semua orang, karena berlari berarti melakukan perpindahan tempat dari suatu titik ke titik yang lain 
dengan ketentuan pada saat melakukan perpindahan terjadi posisi melayang atau ada saatnya salah satu anggota tubuh (telapak kaki) tidak menyentuh tanah. Menurut Lukman terdapat dua ciri berlari yaitu: (1) saat berlari ada kurun waktu yang pendek dimana tidak ada hubungan dengan permukaan, (2) berlari tidak ada kurun waktu dimana kedua kaki berhubungan dengan permukaan pada waktu yang sama, Lukman O.T (2003: 121).

Urutan langkah dalam setiap berlari akan mengalami fase menopang (support phase) dan fase melayang (flight phase). Langkah ini dapat dirinci menjadi fase topang depan dan fase dorong bagi kaki topang dan fase melayang yang dirinci menjadi fase ayun depan dan fase pemulihan, Didik Zafar Sidik (2011: 10). Pada saat melakukan fase topang depan akan terjadi perlambatan dorongan badan ke depan kemudian dipercepat kembali oleh fase dorong. Fase melayang kaki bebas mengayun mendahului badan dan diluruskan untuk persiapkan menyentuh tanah dan yang terakhir yaitu kaki topang dibengkokkan dan diayun kebadan, untuk lebih jelasnya dapat dilihat pada gambar 1 .

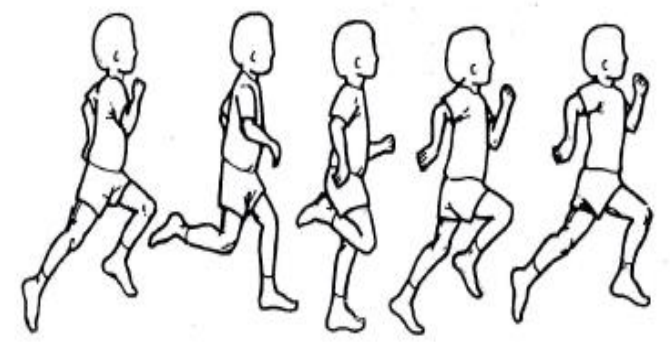

Gambar 1. Gerakan Lari, Gallahue and Ozmun (2006: 211)

Kegiatan pada gambar 1 yaitu fase topang, fase melayang akan terjadi secara terus menerus selama seseorang melakukan kegiatan berlari. Unsur-unsur berlari dapat dibagi menjadi tiga kategori yaitu: (1) awalan, merupakan sikap saat melakukan start, yaitu: bersedia, siap dan ya, (2) berlari, sikap badan saatmelakukan berlari yaitu: sikap badan condong kedepan, ayunan tangan dan ayunan tungkai. Sementara menurut Gallahue and Ozmun (2006: 210) tahapan pematangan dalam gerakan lari adalah sebagai berikut: Mature Stage; (1) Stride length at maximum; stride speed fast, (2) Definite flight phase, (3) Complete extension of support leg, (4) Recovery thigh parallel, (5) Arms swing vertically in opposition to legs, (7) Arms bent at approximate right angles, (8) Minimal rotary action of recovery leg and foot. Maksudnya pada tahap matang gerak dasar lari 1) Panjang langkah maksimal; kecepatan langkahnya cepat; 2) Fase melayang tepat, 3) Perpanjangan lengkap leg dukungan; 4) Pemulihan paha paralel; 5) Lengan diayunkan secara vertikal berlawanan dengan kaki; 6) Lengan membungkuk di sudut kanan perkiraan; 7) Tindakan rotary minimal kaki pemulihan dan kaki.

Lari dengan ujung kaki adalah: pelari saat melangkahkan salah satu kakinya kedepan, kaki belakang yang paling terakhir menyentuh tanah adalah ujung kaki, demikian juga pada saat kaki depan mendarat di tanah yang paling dahulu menyentuh tanah adalah ujung kaki. 
Lari dengan lutut atau paha di anggkat tinggi yaitu: pelari saat mengayun kaki belakang kedepan secara bergantian lututnya atau pahanya dianggkat tinggi untuk memperlebar langkah sekaligus memperlambat ujung kaki menyentuh tanah.

Lari dengan ayunan lengan atau tangan yaitu: bahwa pada saat kita berlari kedua lengan atau tangan diayun dari belakang ke depan secara bergantian dan dibengkokkan hingga membentuk sudut Sembilan puluh derajat $\left(90^{\circ}\right)$, gerakan ini dimaksudkan untuk memberikan keseimbangan dan daya dorong kedepan, telapak tangan terbuka.

Lari dengan badan condong kedepan yaitu: bahwa pada saat berlari badan hendaknya condong kedepan secara wajar dan otot sekitar leher dan rahang tetap rileks dengan kepala dan punggung dalam posisi segaris.

Permainan benteng merupakan salah satu permainan tradisional yang dilakukan oleh dua regu. Setiap regu terdiri atas 4-8 orang. Setiap regu akan memilih suatu tempat sebagai markas, biasanya berupa tiang, batu, maupun pilar rumah sebagai benteng.

Olahraga ini bertujuan untuk menyerang dan mengambil alih benteng lawan. Caranya dengan menyentuh benteng yang menjadi markas regu lawan sambil meneriakkan kata "benteng". Kemenangan dapat diraih sebuah rgu jika berhasil menawan seluruh anggota regu lawan dengan menyentuh tubuhnya. Untuk menentukan regu yang berhak menjadi penawan atau tertawan dapat ditentukan berdasarkan waktu terakhir ketikan si penawan atau tertawan menyentuh benteng mereka masing-masing.

Regu yang berhak menjadi penawan adalah regu yang waktunya paling cepat ketika menyentuh benteng. Regu ini dapat mengejar dan menyentuh anggota regu lawan untuk menjadikannya tawanan. Tawanan akan ditempatkan di sekitar benteng musuh dan dapat dibebaskan teman regu yang di tawan menyentuh dirinya.

Pada permainan ini, tiap-tiap anggota regu memiliki tugas antara lain sebagai penyerang, mata-mata, pengganggu, maupun penjaga benteng. Permainan ini membutuhkan kecepatan berlari dan keamampuan strategi yang tepat, Ajun Khamdari (2010: 15)

Permainan ini dilakukan dengan saling mengejar antara anggota regu, berikut lapangan permainan benteng dapat dilihat pada gambar 5 .

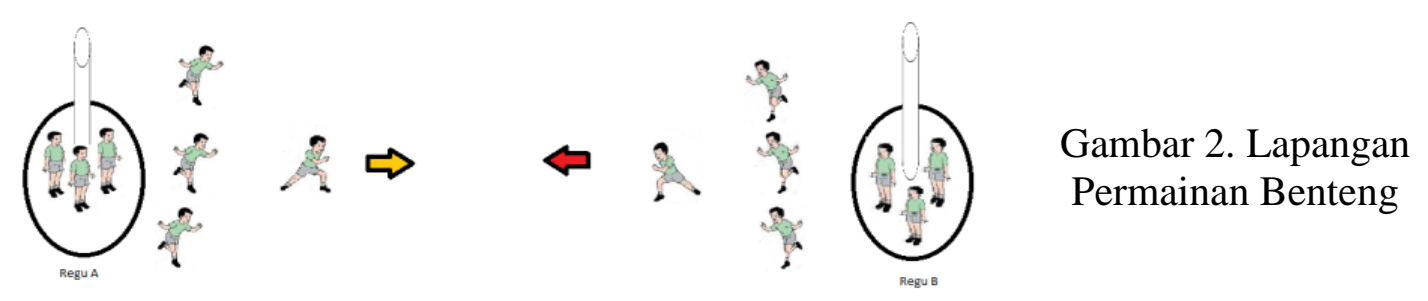


Keterangan gambar:

$$
\begin{aligned}
\bigcirc & =\text { Benteng Regu } \\
\longrightarrow & =\text { Arah Lari Regu A } \\
\longleftarrow & =\text { Arah Lari Regu B }
\end{aligned}
$$

Permainan memindaahkan bola merupakan permainan yang dimainkan oleh anak-anak secara berkelompok, dalam permaianan ini setiap kelompok beranggotakan tiga orang. Permainan ini dimainkan oleh anak laki-laki maupun perempuan, permainan ini bersifat kompetisi karena kelompok yang dianggap menang adalah kelompok yang tercepat dalam memindahkan bola dari tempat awal ke tempat yang tersedia. Permainan ini merupakan pengembangan dari permainan pindah barang menurut A. Husna M, (2009: 53).

Dalam pelaksanaan permainan ini dibutuhkan kebugaran jasmani, kecepatan berlari, kelincahan, keseimbangan, kekuatan serta daya tahan jantung dan paru. Peralatan yang dibutuhkan setiap kelompok dalam permainan ini adalah tiga buah bola berukuran kecil atau berukuran dengan diameter sekitar 2-3 $\mathrm{Cm}$ dan tiga buah cone dengan ukuran yang diletakkan dengan jarak 3 meter setiap cone.

Dikatakan permainan memindahkan bola karena, bola yang diletakkan dalam wadah yang berada pada garis star kemudian bola tersebut dibawa kearah kone dan diletakkan diatas cone yang telah ditentukan. Permainan ini dalam pelaksanaannya terjadi saling adu kecepatan antara anggota kelompok yang satu dengan anggota kelompok yang lainnya, berikut lapangan permainan memindahkan bola.

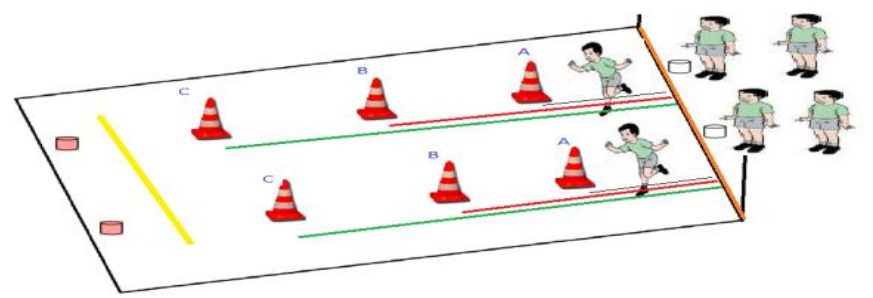

Gambar Permainan

3. Lapangan Bola

Keterangan Gambar: 3

\section{$=$ Tempat bola di garis start}

= Tempat bola di garis finish

$=$ Garis start

$=$ Garis finish

- Siswa lari membawa bola ke arah cone A, meletakkan bola di atas cone $\mathrm{A}$ kemudian kembali kegaris start dan mengambil bola

$=$ Siswa lari ke arah cone $\mathrm{B}$, mengambil bola di atas cone $\mathrm{B}$ kemudian kembali kegaris start dan mengambil bola

$=$ Siswa lari ke arah cone $\mathrm{B}$, meletakkan bola di atas cone $\mathrm{B}$ kemudian kembali kegaris start dan mengambil bola 
Hipotesis yang di ajukan dalam penelitian ini adalah: (1) Terdapat kontribusi permainan benteng terhadap gerak dasar lari siswa Taman kanak-kanak kelurahan payo selincah, (2) Terdapat kontribusi permainan memindahkan bola terhadap gerak dasar lari siswa Taman kanak-kanak kelurahan payo selincah, (3) Terdapat perbedaan kontribusi permainan benteng dan memindahkan bola terhadap gerak dasar lari siswa Taman kanak-kanak kelurahan payo selincah.

\section{Metode}

Metode penelitian yang digunakan dalam penelitian ini adalah metode eksperimen two group pretest posttest design, sebagaimana diungkapkan Sugiyono (2008: 107) bahwa dalam penelitian eksperimen ada perlakuan (treatment), Dengan demikian penelitan eksperiment dapat diartikan sebagai metode yang digunakan untuk mencari pengaruh perlakuan tertentu terhadap yang lain dalam kondisi terkendali. Apa yang diungkapkan oleh Sugiyono di atas sejalan dengan apa yang dilakukan dalam penelitian ini.

Penelitian ini terdiri dari variabel terikat yaitu kemampuan gerak dasar lari, variabel bebas yaitu permainan benteng dan memindahkan bola, rancangan perlakuan sebabgai berikut:

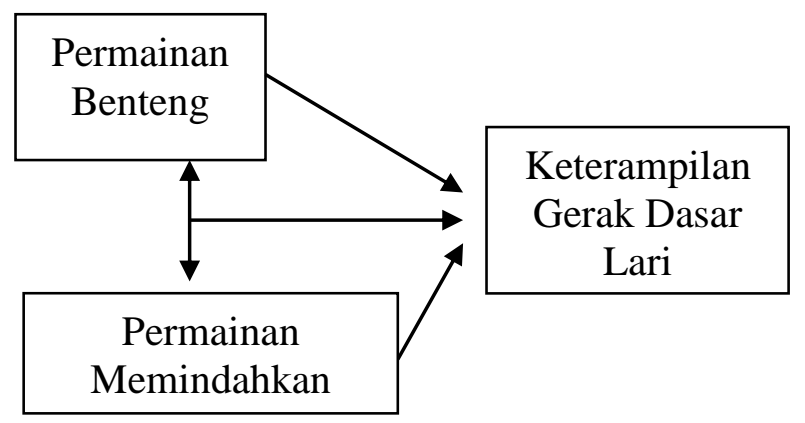

Penelitian ini dilaksanakan di taman kanak-kanak PKK Kelurahan Payo Selincah Kota Jambi, dilaksanakan selama kurang lebih 6 (enam) minggu, dengan prekuensi latihan 3 (tiga) kali dalam seminggu, sekali latihan berlangsung selama 45 - 60 menit, dengan demikian jumlah pertemuan 18 kali pertemuan, termasuk pelaksanaan tes awal dan tes akhir.

Sebelum pelaksanaan penelitian terlebih dahulu dilakukan uji coba instrument penilaian kemampuan gerak dasar lari kepada siswa taman kanak-kanak yang memiliki karakteristik sama atau hampir sama dengan sampel penelitian, kemudian dianalisis untuk melihat validitas dan reabilitasnya.

Populasi penelitian ini adalah seluruh siswa-siswi taman kanak-kanak tahun ajaran 2015/2016 Sekelurahan Payo Selincah Kecamatan Jambi Timur Kota Jambi yang berjumlah 86 siswa taman kanak-kanak Bintang. Sementara itu sampel penelitian ini berjumlah 46 siswa. Teknik pengambilan sampel dilakukan dengan teknik simple random sampling (sampel acak). Menurut Sugiyono (2013: 58) bahwa; "teknik simple random sampling dilakukan apabila anggota populasi dianggap 
homogen. Setelah didapatkan sampel maka dilakukan pengundian kembali untuk penempatan bentuk permainan yang di ikuti. Berdasarkan kegiatan di atas, maka dapat dilakukan pengelompokkan sampel seperti berikut:

Teknik pengumpulan data dalam penelitian ini adalah dengan melakukan tes pengamatan dengan menggunakan panduan lembar pengamatan untuk mendapatkan data keterampilan lari sprint dilakukan dengan cara sebagai berikut:

1. Dilakukan tes pelaksanaan menggunakan start melayang, dengan menggunakan aba-aba bersedia, siap, ya.

2. Dilakukan tes kemampuan gerak dasar lari dengan jarak 40 meter (dilakukan pengamatan terhadap kemampuan gerak dasar lari yang dilakukan)

\section{Pembahasan}

\section{Kontribusi Permainan Benteng Terhadap Keterampilan Gerak Dasar Lari}

Berdasarkan hasil analisis data diperoleh $\mathrm{t}$ hitung $>\mathrm{t}$ table $(4,91>1,71)$. Hal ini berarti terdapat kontribusi yang signifikan permainan banteng terhadap keterampilan gerak dasar lari. Ini membuktikan bahwa permainan banteng memiliki kontribusi dalam meningkatkan keterampilan gerak dasar lari.

Kegiatan berlari pada permainan benteng itu selalu dilakukan oleh setiap anggota regu. Baik itu berlari dengan tujuan menangkap anggota regu lain ataupun menghindari diri dari tangkapan anggota regu lain. Sehingga setiap anggota regu permainan tersebut berusaha untuk melakukan gerak dasar lari seefesien mungkin sehingga laju larinya dapat meningkat.

Dalam melakukan permainan benteng, secara tidak sengaja setiap anggota regu yang melakukan aktivitas berlari berusaha memperbaiki teknik berlarinya. Hal ini dapat dilihat adanya perubahan dalam melakukan ayunan lengan secara bergantian dengan posisi tangan berada di samping dada, melakukan gerakan mengangkat kaki dengan cara mengangkat lutut atau paha secara bergantian dan mempersiapkan kaki untuk mendarat, sementara kaki lain sebagai kaki topang dibengkokan untuk persiapan diayunkan kedepan. Pelaku juga dalam berlari mengarahkan pandangan kedepan kearah yang dituju.

\section{Kontribusi Permainan Memindahkan bola Terhadap Keterampilan Gerak Dasar Lari}

Berdasarkan hasil analisis data diperoleh $\mathrm{t}$ hitung $>\mathrm{t}$ table $(8,2>1,71)$. Hal ini berarti terdapat kontribusi yang signifikan permainan memindahkan bola terhadap keterampilan gerak dasar lari. Ini membuktikan bahwa permainan memindahkan bola memiliki kontribusi dalam meningkatkan keterampilan gerak dasar lari.

Sama halnya dengan permainan benteng, permainan memindahkan bola mengandung unsur kegiatan berlari secara bebas sebatas garis yang telah ditentukan serta kegiatan memutar badan dengan cepat untuk kembali ke garis start atau ke garis finish. Melakukan kegiatan berlari saat melakukan permainan memindahkan bola 
prosesnya hampir sama dengan melakukan permainan benteng. Permainan memindahkan bola sengaja di atur dalam bentuk kelompok. Dengan demikian siswa merasa selalu berkompetisi dalam memindahkan bola tersebut.

Dengan adanya rasa kompetisi memuat siswa lebih bersemangat dan berusaha menjadi yang tercepat. Kegiatan ini berdampak kepada keterampilan gerak dasar lari siswa. Siswa berusaha melakukan gerakan lari secara efektif dengan cara melakukan ayunan lengan secara bergantian dengan posisi tangan berada di samping dada, melakukan gerakan mengangkat kaki dengan cara mengangkat lutut atau paha secara bergantian dan mempersiapkan kaki untuk mendarat, sementara kaki lain sebagai kaki topang dibengkokan untuk persiapan diayunkan kedepan.

\section{Terdapat Perbedaan Kontribusi Permainan Banteng dan Memindahkan bola Terhadap Keterampilan Gerak Dasar Lari}

Untuk menganalisis hasil eksperimen dapat dilakukan dengan menganalisis data tes akhir keterampilan sampel kelompok permainan benteng dan kelompok permainan memindahkan bola dengan lembar observasi keterampilan gerak dasar lari melalui analisis uji-t. Berdasarkan hasil analisis data diperoleh $\mathrm{t}$ hitung $>\mathrm{t}$ table $(1,82>1,71)$. Hal ini berarti terdapat perbedaan kontribusi yang signifikan antara permainan banteng dan memindahkan bola terhadap keterampilan gerak dasar lari. Ini membuktikan bahwa permainan memindahkan bola memiliki kontribusi dalam meningkatkan keterampilan gerak dasar lari.

Perbedaan kontribusi ini di sebabkan oleh peraturan permainan yang berbeda. Pada kedua permainan ini siswa dituntut untuk berlari. Akan tetapi permainan benteng memiliki perbedaan dalam pola berlari bila dibandingkan dengan permainan menaruh bola.

Pada permainan benteng setiap anggota regu melakukan aktivitas berlari untuk menangkap atau menghindar dari tangkapan anggota regu lawan. Sehingga pola berlari siswa pada permainan benteng tidak tetap. Terkadang berlari menuju arah depan dan tidak jarang mereka melakukan perubahan arah berlari seperti kearah serong kiri atau kanan maupun hingga belok ke kiri maupun ke kanan. Dengan adanya pola yang tidak beraturan tersebut siswa kesulitan delam memperbaiki keterampilan gerak dasar berlari karena jarak yang digunakan telalu pendek.

Pada umumnya dalam permainan benteng siswa selalu merubah arah lari dalam langkah ke 2-3 sehingga mengganggu keseimbangan dalam berlari. Keseimbangan mempengaruhi kemampuan siswa untuk berlari. Dengan adanya keseimbangan yang baik maka koordinasi gerakan tangan dan kaki saat berlari akan selalu terjaga. Oleh karena itu siswa pada kelompok permaianan benteng membutuhkan waktu yang cukup lama dalam meningkatkan keterampilan gerak dasar berlari.

Berbeda dengan permainan benteng, permainan menaruh bola memiliki pola yang selalu konstan yaitu berlari menuju arah depan dan berbalik ketika bola telah diletakan diatas cone. Hal ini membuat siswa terbiasa dengan pola lari yang lurus 
kedepan. Sehingga pengalaman pola lari ke arah depan lebih banyak bila dibandingkan dengan siswa pada kelompok permainan benteng.

Dalam permaianan memindahkan bola jarak antara cone selalu tetap yang membuat siswa mapu merencanakan pembalikan dengan baik sehingga keseimbangan saat berlari selalu terjaga. Memiliki jarak yang lebih jauh untuk merubah arah larinya.

Berdasarkan pola lari yang dilakukan pada kedua kelompok permainan tersebut terdapat perbedaan kontribusi antara permainan benteng dan memindahkan bola. Siswa pada kelompok permainana memindahkan bola lebih baik keterampilan gerak dasar lari bila dibandingkan dengan siswa pada kelompok permainan benteng.

\section{Simpulan}

Berdasarkan analisis data dan pembahasan, maka penelitian ini dapat disimpulkan sebagai berikut:

1. Permainan benteng memberikan kontribusi terhadap peningkatan keterampilan gerak dasar lari pada siswa TK Bintang kelurahan payo selincah.

2. Permainan memindahkan bola memberikan kontribusi terhadap peningkatan keterampilan gerak dasar lari pada siswa TK Bintang kelurahan payo selincah.

3. Permainan memindahkan bola memiliki kontribusi yang lebih baik dari pada permainan benteng terhadap peningkatan keterampilan gerak dasar lari pada siswa TK Bintang kelurahan payo selincah

\section{Rujukan}

A. Husna M, 2009. 100+Permainan Tradisional Indonesia, untuk kreativitas, Ketangkasan, dan Keakraban, Yogyakarta, Andi Offset.

Dikdik Zafar Sidik, 2011. Mengajar dan Melatih Atletik (Bandung: PT. Remaja Rosdakarya offset.

Dini Rosdiani, 2012. Model Pembelajaran Langsung dalam Pendidikan Jasmani dan Kesehatan, Bandung: ALFABETA.

H.Y.S. Santosa Giriwijoyo dan Didik Zafar Sidik, 2012, Ilmu Kesehatan Olahraga, Bandung P.T. Remaja Rosdakarya Offset.

Undang-undang Republik Indonesia Nomor 20 tahun 2003, tentang Sistem Pendidikan Nasional, Bab II, Pasal 3.

Undang-undang Republik Indonesia nomor 3 tahun 2005, tentang Sistem Keolahragaan Nasional, pada Bab VI pasal 18 ayat 8.

Undang-undang Republik Indonesia Nomor 14 tahun 2005, tentang Guru dan Dosen W.S, Winkell. 2001 Psikologi Pengajaran. Yogyakarta: PT. Gramedia. 